\title{
Cultivation of Azospirillum brasilense in Vinasse and Potential Use in Fertigation
}

\author{
Marcelo Teixeira Silva \\ Postgraduate Program in Clean Technologies, Cesumar University (Unicesumar), Brazil
}

Francielli Gasparotto

Cesumar University (Unicesumar) and Cesumar Institute of Science, Technology and Innovation - ICETI, Brazil

Bárbara Maria Lustri, Natalia Caetano Vasques

Postgraduate Program in Clean Technologies, Cesumar University (Unicesumar), Brazil

Natália Ueda Yamaguchi

Cesumar University (Unicesumar) and Cesumar Institute of Science, Technology and Innovation - ICETI, Brazil

Received: Oct. 22, $2020 \quad$ Accepted: Dec. 9, $2020 \quad$ Published: Dec. 10, 2020

doi:10.5296/jas.v8i4.17862 URL: https://doi.org/10.5296/jas.v8i4.17862

\begin{abstract}
Vinasse, residue from the sugar-energy sector, has been applied as a fertilizer in sugarcane fields due to its nutritional characteristics, which may reduce nitrogen fertilization, especially if associated with diazotrophic bacteria. The objective was to evaluate the use of vinasse as culture medium for Azospirillum brasilense and the chemical changes caused in the residue after bacterial colonization. The experimental design was completely randomized with 9 treatments: T0-control (nutrient broth DYGs inoculated with A. brasilense); T1- 100\% vinasse inoculated with $A$. brasilense; T2- 75\% vinasse inoculated with $A$. brasilense; T3$25 \%$ vinasse inoculated with $A$. brasilense; T4- 50\% vinasse inoculated with A. brasilense; T5- 100\% vinasse; T6- 75\% vinasse; T7- 25\% vinasse and T8- 50\% vinasse. Microbial growth was evaluated in a spectrophotometer, by turbidimetry (700nm). Chemical characterization of vinasse was carried out before bacterial inoculation and on days 1, 3, 5
\end{abstract}


and 7 after inoculation according to the methodologies of the Standard Methods for the Examination of Water and Wastewater $22 \mathrm{ND}$ for the elements nitrogen (4500-Norg), phosphorus (4500-P), potassium (3030-A) and calcium (3500 Ca-B). The determination of organic matter was carried out in accordance with the technical standard NBR 13600. The bacteria $A$. brasilense survived and multiplied in sugarcane vinasse, causing changes such as the increase in the levels of phosphorus and nitrogen and the reduction of the organic load, mainly in pure vinasse $(100 \%)$, indicating that the viability of this practice for the application of these organisms in the culture of sugar cane via fertigation.

Keywords: sugarcane, biological nitrogen fixation, sustainability

\section{Introduction}

Brazil has been producing ethanol on a large scale for automotive fuel for 30 years. In Brazilian plants, for each liter of ethanol produced, between 9 and 14 liters of vinasse are generated (ESPANA-GAMBOA et al., 2011). Considering a production of approximately 35 billion liters of ethanol in the 2019/20 harvest (MAPA, 2020), it is estimated that the average production of vinasse was approximately 420 billion liters.

The destination of vinasse represents one of the main burdens of the sugar and alcohol industry in Brazil (FUESS et al., 2018), with acid pH (4.3) and high chemical oxygen demand (COD $23,801 \mathrm{mg} \mathrm{L}^{-1}$ ) as its main characteristics, which may cause a hundred times greater impact than domestic sewage (SEIXAS et al., 2016; ESPANA-GAMBOA et al., 2011).

Due to these characteristics, combined with the high volume of generation, the proper disposal of the waste becomes necessary. In Brazil, vinasse is commonly applied to the soil as a fertilizer for the cultivation of sugar cane due to its high levels of organic matter and nutrients, especially potassium, but also nitrogen and phosphorus (CRUZ et al., 2013).

Although studies have associated beneficial results with fertigation (SILVA et al., 2007; CRUZ et al., 2013), including reduced spending on inorganic fertilizers, the disposal of vinasse in the soil, can have negative impacts on the soil-water system. long-term plant such as soil salinization and subsequent structural destabilization of the soil, losses of microbial activity and soil acidification, contamination of surface water, leaching of nitrates from the soil (CHRISTOFOLETTI et al., 2013; FUESS; GARCIA, 2014; FUESS et al., 2017; FUESS et al., 2018).

Even though economic perspectives point to fertigation as a simple and low-cost solution for the disposal of vinasse in abundance (PRADO et al., 2017; ORTEGÓN et al., 2016), complementary technologies must be researched to mitigate the impacts negative effects of long-term fertigation. In this context, studies related to the use of vinasse as a culture medium for microorganisms have been reported, since some organisms can produce value-added by-products and reduce the polluting load of this residue (CARDOSO; ARAÚJO, 2011; GASPAROTTO et al., 2019; RULLI et al., 2020).

In the quest to optimize cane production and reduce environmental impacts, an alternative would be the use of bacteria that promote plant growth and fix atmospheric nitrogen (PEDULA et al., 2016; KHAN et al., 2020). With emphasis on the genus Azospirillum, one of the most 
widely studied and commercially used in agriculture (CASSÁN; DIAZ-ZORITA, 2016; PEDRAZA et al., 2020), including cane (SCHULTZ et al., 2014; TORTORA et al., 2019).

The inoculation of these bacteria usually occurs via spraying (SCHULTZ et al., 2014; CONIGLIO et al., 2019), an option to reduce application costs and damage to the culture would be their application via fertigation, however, there are few studies on the survival of these organisms and the alterations that they can cause in the vinasse. Thus, the objective was to evaluate the use of vinasse as a culture medium for the bacteria A. brasilense and the chemical changes caused in the residue after bacterial colonization.

\section{Method}

\subsection{Experimental Design and Treatments}

The experiment was carried out at the Soil Chemistry Laboratory at Cesumar University (Unicesumar), Maringá-Paraná-Brazil. The experimental design was completely randomized with nine treatments and five replications / treatment, totaling 45 experimental units. These were composed of different concentrations of vinasse, being: T0 (control - nutrient broth DYGs inoculated with A. brasilense), T1 (100\% inoculated vinasse with A. brasilense), T2 (75\% vinasse and $25 \%$ distilled water inoculated with $A$. brasilense), T3 (25\% vinasse and $75 \%$ distilled water inoculated with $A$. brasilense), T4 (50\% vinasse and 50\% distilled water inoculated with $A$. brasilense), T5 (100\% vinasse), T6 (75\% vinasse and 25\% distilled water), $\mathrm{T} 7$ (25\% vinasse and $75 \%$ distilled water) and T8 (50\% vinasse and 50\% distilled water).

\subsection{Vinasse and Bacterial Inoculation}

The vinasse used was supplied by a sugar and alcohol plant located in Maringá-Paraná-Brazil, this was collected at the end of the distillation column and stored in a $10 \mathrm{~L}$ plastic reservoir. The media were prepared for a final volume of $250 \mathrm{~mL}$, packed in $500 \mathrm{~mL}$ erlenmeyer according to each treatment. For the inoculation of the culture media, a $2 \mathrm{~mL}$ aliquot $(4.0 \mathrm{x}$ 108 cells.ml $^{-1}$ ) of the bacteria Azospirillum brasilense, strains AbV5 and AbV6 (UFPR) provided by Microquímica (Azzofix ${ }^{\circledR}$ ) were used. After inoculation, the containers were placed on an orbital shaker table (120 rpm), at room temperature and constant agitation.

\subsection{Determinations}

Microbial growth was evaluated in a spectrophotometer, by turbidimetry, with a wavelength of 700nm. For the chemical characterization of vinasse before and after inoculation, the methodologies proposed by the Standard Methods for the Examination of Water and Wastewater 22 ND (APHA, 2012) were used. To determine total nitrogen, the Kjeldahl method (method 4500-NorgB) was used; the determination of phosphorus was performed according to Method 4500-P-E, potassium, as described in method 3030-A and for calcium, the methodology $3500 \mathrm{Ca}-\mathrm{B}$ was used.

Only the determination of Organic Matter (OM) was performed according to the ABNT method Brazilian Association of Technical Standards (1996), by the technical standard NBR 13600. The first evaluation was carried out immediately after inoculation of the media, the second evaluation after 24 hours and thereafter every 48 hours, totaling five assessments, at 0, 1, 3, 5 and 7 days. 


\subsection{Statistical Analyzes}

Statistical analyzes were performed for the experimental data in quadruplicate and the results were submitted to a single factor analysis of variance (ANOVA) of 5\% probability and the

significant qualitative responses were submitted to the Scott-Knott test considering the same level of significance, 5\%. For the development of statistical analysis, Sisvar software was used (FERREIRA, 2007).

\section{Results and Discussion}

Vinasse proved to be viable for use as a means of multiplication of A. brasilense, the results revealed satisfactory performance of bacterial growth (Figure 01-A). The best growth performance occurred in the treatment with culture medium based on $100 \%$ vinasse, surpassing the cultivation in nutrient broth.

Vinasse presents concentrations of soluble organic and inorganic material favorable to bacterial growth (SHI; ZHU, 2007), however different from that observed in this study for the bacterium Bacillus subtilis, lower concentrations of vinasse $(25 \%)$ were those that provided the greatest multiplication (CARDOSO; ARAÚJO, 2011).

Associated with the increase in the bacterial population, an increase in nitrogen levels was detected, mainly in the samples of nutrient broth DYGs and in the concentrations of $100 \%$ and $75 \%$ of vinasse, both inoculated (Figure 01-B). Demonstrating that A. brasilense multiplied in the treatments and even released nitrogen in the samples.
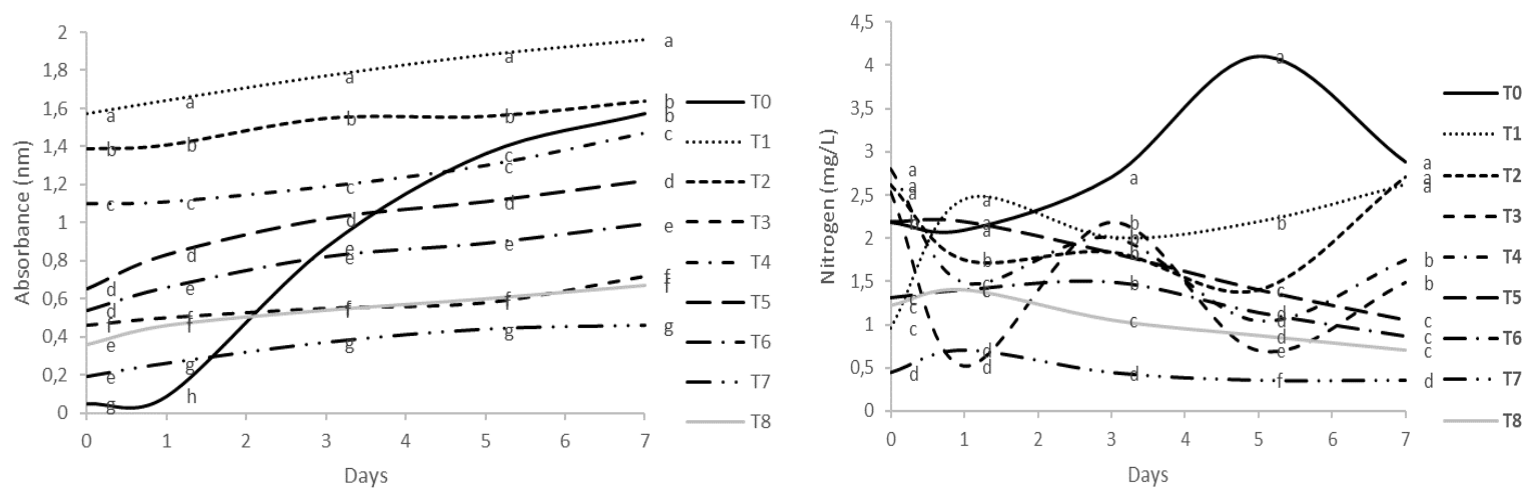

Figure 01. Average values of: A - absorbance (nm); B - Nitrogen (mg/L)

*Treatments: T0- control (nutrient broth DYGs inoculated with Azospirillum brasilense); T1100\% vinasse inoculated with Azospirillum brasilense; T2- 75\% vinasse inoculated with Azospirillum brasilense; T3- 25\% vinasse inoculated with Azospirillum brasilense; T4- 50\% vinasse inoculated with Azospirillum brasilense; T5- 100\% vinasse; T6- 75\% vinasse; T7$25 \%$ vinasse and $\mathrm{T} 8-50 \%$ vinasse.

In the lowest concentrations of inoculated vinasse and in non-inoculated treatments, negative variations in nitrogen levels occurred. It was observed that between the first and the last evaluation there were reductions in the order of $70 \%, 60 \%, 108 \%, 50 \%, 25 \%$ and $74 \%$ from 


\section{MInstitute"}

$\mathrm{T} 3$ to $\mathrm{T} 8$, respectively.

The survival and multiplication of $A$. brasilense in vinasse in the highest concentrations evaluated is a promising alternative for the application of these microorganisms via fertigation in the culture of sugarcane. The use of bacteria of the genus Azospirillum, promoters of plant growth and nitrogen fixers directly contribute to the nitrogen nutrition of several non-leguminous species, favoring their growth and decreasing the use of nitrogen fertilizers, without decreasing productivity (CASSÁN; DIAZ-ZORITA, 2016).

In the treatments with inoculated vinasse, significant variations occurred between the evaluations regarding the available phosphorus content detected in the samples, in the order of $119,183,394$ and $305 \%$, for T1, T2, T3 and T4, respectively, between the first and the last evaluation. These results indicate that the inoculated bacteria released this nutrient present in the solids in the vinasse (Figure $02-\mathrm{A}$ ). What did not happen in the treatments without inoculation of A. brasilense.
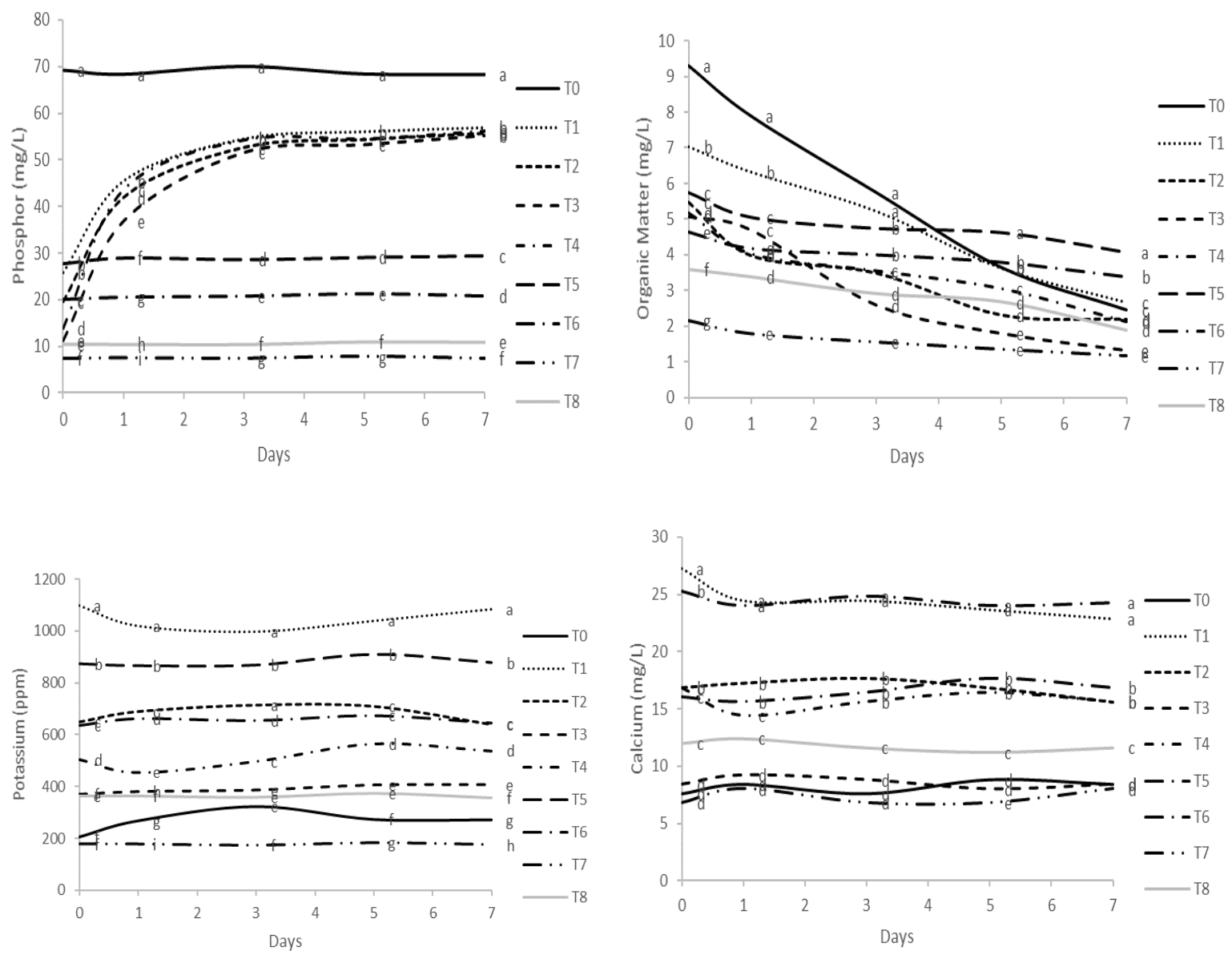

Figure 02. Average values of: A - Phosphorus (mg/L), B - Organic matter (mg/L), C Potassium (ppm) and D - Calcium (mg/L)

*Treatments: T0- control (nutrient broth DYGs inoculated with Azospirillum brasilense); T1100\% vinasse inoculated with Azospirillum brasilense; T2- 75\% vinasse inoculated with Azospirillum brasilense; T3- 25\% vinasse inoculated with Azospirillum brasilense; T4- 50\% 
vinasse inoculated with Azospirillum brasilense; T5- 100\% vinasse; T6- $\quad 75 \%$ vinasse; T7$25 \%$ vinasse and $\mathrm{T} 8-50 \%$ vinasse.

The increase in phosphorus contents observed is possibly due to phosphorus solubilization. Phosphate solubilizing microorganisms, such as Azospirillum sp., Can secrete organic acids that dissolve phosphate minerals and release inorganic phosphorus (PEDRAZA et al., 2020). Corroborating these results, Kazi et al. (2016) state that bacteria of this genus can perform phosphate solubilization and still provide greater root development of inoculated plants.

Costa et al. (2015), when studying the ability of associative diazotrophic bacteria to solubilize phosphate, obtained a positive response from four of the five strains used, which caused an increase in the growth of rice plants and the accumulation of nutrients through the solubilization of calcium phosphate.

The increased availability of phosphorus in vinasse through the action of inoculated bacteria is a beneficial aspect, as it is an essential nutrient for sugarcane plants, which can result in less use of phosphate fertilizers.

In parallel with the increase in phosphorus levels, there were progressive and significant reductions in the values of organic matter (M.O.), with emphasis on inoculated treatments (Figure 2- B). In treatments that were not inoculated with the bacteria (T5, T6, T7 and T8), there was also a reduction in the M.O. content, but less marked when compared to the inoculated treatments (T1, T2, T3 and T4). It is observed that the higher the concentration of vinasse in the treatments, the greater the reduction of organic matter.

The biodigestion of vinasse with microorganisms causes the reduction of the organic matter present, reducing the polluting potential of this residue, however it does not change the content of nutrients present (FUESS et al., 2018). In this sense, no significant variations were observed in the levels of potassium and calcium (Figures 2C and 2D) in any of the treatments, which shows that the multiplication of $A$. brasilense did not significantly change the levels of these elements.

The highest levels of potassium were observed in treatments with a higher concentration of vinasse, treatments where there was also greater multiplication of bacteria and reduction of organic matter. It is noteworthy that vinasse is a waste with a high potassium content, which, if not properly handled, has a high potential for environmental contamination (ESPANA-GAMBOA et al., 2011; FUESS; GARCIA, 2014).

The reduction of the organic matter content observed in the treatments inoculated with $A$. brasilense, theoretically reduces the polluting potential of this residue, since it will prevent the clogging of the soil pores with a consequent reduction in the concentration of dissolved oxygen and a decrease in the activity of microorganisms, impacts pointed out by several authors as expected from the continuous application of vinasse in agricultural fields (ESPANA-GAMBOA et al., 2011; FUESS; GARCIA, 2014; PALACIOS-BERECHE et al., 2020).

\section{Conclusion}

The bacterium A. brasilense survived and multiplied in sugarcane vinasse, causing changes 
such as increased levels of phosphorus and nitrogen and reduced organic load, especially in pure vinasse $(100 \%)$, indicating that the viability of this practice for the application of these organisms in sugarcane cultivation via fertigation.

It is noteworthy that studies are needed to evaluate the ideal time between inoculation of vinasse with $A$. brasilense and its application in sugarcane. And the possible benefits or impacts that this practice can have on both the crop and the environment.

\section{References}

ABNT - Brazilian Association of Technical Standards, NBR 13600. (1996)

APHA - Standard Methods for the Examination of Water and Wastewater, 22nd Ed.: American Public Health Association, American Water Works Association, Water Environment Federation. Washington, DC. 2012.

Cardoso, R. B., \& Araújo, F. F. (2011). Multiplicação de Bacillus subtilis em vinhaça e viabilidade no controle da meloidoginose em cana-de-açúcar. Revista Brasileira de $\begin{array}{llll}\text { Engenharia Agrícola } \quad e \quad \text { Ambiental, } & 15(12), & 1283-1288 .\end{array}$ https://www.scielo.br/pdf/rbeaa/v15n12/a10v15n12.pdf

Cassán, F.; \& Diaz-Zorita, M. (2016). Azospirillum sp. in current agriculture: From the laboratory to the field. Soil Biology and Biochemistry, 103, 117-130. https://doi.org/10.1016/j.soilbio.2016.08.020.

Christofoletti, C.A., Escher, J.P., Correia, J.E., Marinho, J.F., \& Fontanetti, C.S. (2013). Sugarcane vinasse: environmental implications of its use. Waste Management, 33(12), 2752-2761. https://doi.org/10.1016/j.wasman.2013.09.005

Coniglio, A., Mora, V., Puente, M., \& Cassán, F. (2019). Azospirillum as biofertilizer for sustainable agriculture: Azospirillum brasilense AZ39 as a Model of PGPR and Field Traceability. In: Zúñiga-Dávila, D., González-Andrés, F., Ormeño-Orrillo, E. Microbial Probiotics for Agricultural Systems. Sustainability in Plant and Crop Protection, Springer, 44-70. https://doi.org/10.1007/978-3-030-17597-9_4

Costa, E. M., Lima, W., Longatti, O., \& Souza, F. M. (2015). Bactérias solubilizadoras de fosfato aumentam o crescimento de Oryza sativa e o acúmulo de nutrientes em um latossolo fertilizado com fosfato de rocha. Engenharia Ecológica, 83, 380-385.

Cruz, L. F. L. S., Duarte, C.G., Tadeu, F. M., \& Eduardo C. P. (2013). Análise da viabilidade técnica, econômica e ambiental das atuais formas de aproveitamento da vinhaça: fertirrigação, concentração e biodigestão. Revista Brasileira de Ciências Ambientais, 29, 111-127. Disponível em: http://rbciamb.com.br/index.php/Publicacoes_RBCIAMB/article/view/283

Espana-Gamboa, E., Mijangos-Cortes, J., Barahona-Perez, L., Domi-Nguez-Maldonado, J., Hernandez-Zarate, G., \& Alzate-Gaviria, L. (2011). Vinasses: characterization and treatments. Waste Management \& Research, 29(12), 1235-1250.

https://doi.org/10.1177/0734242X10387313 


\section{MInstitute Macrothink $_{\text {Inting }}$}

Journal of Agricultural Studies

ISSN 2166-0379

2020, Vol. 8, No. 4

Ferreira, D. F. (2007). SISVAR: Sistema de Análise de Variância para Dados Balanceados. Versão 5.0. Lavras, DEX/UFLA. (Software estatístico).

Fuess L. T., Garcia, M. L., \& Zaiata, M. (2018). Seasonal characterization of sugarcane vinasse: Assessing environmental impacts from fertirrigation and the bioenergy recovery potential through biodigestion. Science of The Total Environment, 634, 29-40.

https://doi.org/10.1016/j.scitotenv.2018.03.326

Fuess, L. T., \& Garcia, M. L. (2014). Implications of stillage land disposal: a critical review on the impacts of fertigation. Journal of Environmental Management, 145, 210-229. https://doi.org/10.1016/j.jenvman.2014.07.003

Fuess, L. T., Rodrigues, I. J., \& Garcia, M. L. (2017). Fertirrigation with sugarcane vinasse: Foreseeing potential impacts on soil and water resources through vinasse characterization. Journal of Environmental Science Health, 52(11), 1063-1072.

https://doi.org/10.1080/10934529.2017.1338892

Gasparotto, F., Silva, M. T., Watanabe, A. Y. M., Martins, G. M., Silva, C. N., \& Schmidt Filho, E. (2019). Setor sucroenergético e estratégias microbiológicas para mitigação dos impactos ambientais da aplicação da vinhaça. Revista Ibero Americana de Ciências Ambientais, 10(1), 241-251. http://doi.org/10.6008/CBPC2179-6858.2019.001.0020

Kazi, N., Deaker, R., Wilson, N., Muhammad, K., \& Trethowan, R. (2016). The response of wheat genotypes to inoculation with Azospirillum brasilense in the field. Field Crops Research, 196, 368-378. https://doi.org/10.1016/j.fcr.2016.07.012

Khan, M. S., Koizumi, N., \& Olds, J. L. (2020). Biofixation of atmospheric nitrogen in the context of world staple crop production: Policy perspectives. Science of The Total Environment, 701, 134945. https://doi.org/10.1016/j.scitotenv.2019.134945

MAPA - Ministério da Agricultura, Pecuária e Abastecimento. Produção Brasileira de Cana-de-açúcar, Açúcar e Etanol. Available

in:<https://www.gov.br/agricultura/pt-br/assuntos/sustentabilidade/agroenergia/arquivos-prod ucao/001PRODUOBRASILEIRADECANADEACARACAREETANOL_11082020.pdf Accessed on July 25, 2020.

Ortegón, G.P., Arboleda, F. M., Candela, L., Tamoh, K., \& Valdes-Abellan J. (2016). Vinasse application to sugar cane fields. Effect on the unsaturated zone and groundwater at Valle del Cauca (Colombia). Science of The Total Environment, 539, 410-419.

https://doi.org/10.1016/j.scitotenv.2015.08.153

Palacios-Bereche, M. C., Palacios-Bereche, R., \& Nebra, S. A. (2020). Comparison through energy, exergy and economic analyses of two alternatives for the energy exploitation of vinasse. Energy, 197, 117231. https://doi.org/10.1016/j.energy.2020.117231

Pedraza, R. O., Filippone, M. P., Fontana, C., Salazar, S. M., Ramírez-Mata, A., Sierra-Cacho, D., \& Baca, B. E. (2020). Chapter 6 - Azospirillum. In: Amaresan, N., KUMAR, M. S., Annapurna, K., Kumar, K., Sankaranarayanan, A. Beneficial Microbes in Agro-Ecology, 
Academic Press. 73-105. ISBN 9780128234143.

https://doi.org/10.1016/B978-0-12-823414-3.00006-X

Pedula, R. O., Schultz, N., Monteiro, R. C., Pereira, W., Araújo, A. P., Segundo U., \& Reis, V. M. (2016). Growth analysis of sugarcane inoculated with diazotrophic bacteria and nitrogen fertilization. African Journal of Agricultural Research, 11(30), 2786-2795.

https://doi.org/10.5897/AJAR2016.11141

Prado, E. A. F., Vitorino, A. C. T., Mauad, M. E., Paim, S. C., \& Ramão L. (2017). Características tecnológicas da cana-de-açúcar sob aplicação de doses de vinhaça em Latossolo Vermelho distroférrico. Revista de Ciências Agroveterinárias, 16(4), 386-395. https://doi.org/10.5965/223811711642017386

Rulli, M. M., Villegas, L. B., \& Colin, V. L. (2020). Treatment of sugarcane vinasse using an autochthonous fungus from the northwest of Argentina and its potential application in fertigation practices. Journal of Environmental Chemical Engineering, 8(5), 104371. https://doi.org/10.1016/j.jece.2020.104371

Schultz, N., Silva, J.A., Sousa, J.S., Monteiro, R.C., Oliveira, R.P., Chaves, V.A., Pereira, W., Silva, M.F., Reis, V.M., \& Urquiaga, S. (2014). Inoculation of sugarcane with diazotrophic bacteria. Revista Brasileira de Ciências do Solo, 38(2), 407-414.

http://dx.doi.org/10.1590/S0100-06832014000200005

Seixas, F. L., Gimenes, M. L. \& Fernandes-Machado, N. R. C. (2016). Tratamento da vinhaça por adsorção em carvão de bagaço de cana-de-açúcar. Química Nova, 39(2), 172-179. https://doi.org/10.5935/0100-4042.20160013

Shi, F., \& Zhu, Y. (2007). Application of statistically-based experimental designs in medium optimization for spore production of Bacillus subtilis from distillery effluent. Biocontrol, 52, 845-853. https://doi.org/10.1007/s10526-006-9055-z

Silva, M. A. S. Da, Griebeler, N. P., \& Borges, L. C. (2007). Uso de vinhaça e impactos nas propriedades do solo e lençol freático. Revista Brasileira de Engenharia Agrícola $e$ Ambiental, 11(01), 108-114. https://doi.org/10.1590/S1415-43662007000100014

Tortora, M. L., Vera, L., Grellet-Naval, N., Dantur, K., Núñez, M. A., Alderete, M., \& Romero, E. R. (2019). Aislamiento, caracterización y actividad de cepas de Azospirillum brasilense asociadas a la caña de azúcar. Cultivos Tropicales, 40(1), e07. Disponível em: http://scielo.sld.cu/scielo.php?script=sci_arttext\&pid=S0258-59362019000100007\&lng=es\& nrm=iso

\section{Copyright Disclaimer}

Copyright for this article is retained by the author(s), with first publication rights granted to the journal.

This is an open-access article distributed under the terms and conditions of the Creative Commons Attribution license (http://creativecommons.org/licenses/by/4.0/). 